\title{
Intrathecal Magnesium Sulfate in Parturient Undergoing Elective Caesarean Section Under Spinal Anesthesia
}

\author{
ESAM EL-DIN M. ABDALLA, M.D.; SANAA A.A. SOLIMAN, M.D. and AHMED H. MAHMOUD, M.Sc. \\ The Department of Anesthesiology, College of Medicine, Assiut University, Assiut, Egypt
}

\begin{abstract}
Background: A double-blinded, prospective, randomized, controlled study was designed to determine the intensity, duration of block, analgesic efficacy and tolerability of adding magnesium sulphate to intrathecal bupivacaine and fentanyl in partiuents scheduled for elective cesarean section.

Patients and Methods: Sixty patients, age 18 to 45 years, undergo elective cesarean section under spinal anesthesia, ASA physical status I-II, singleton pregnancy and at least 36 weeks gestation. The selected patients were randomly divided into two Groups (A) control group and (B) intrathecal $\mathrm{Mg}$ group). Group (A) was received intrathecal $10 \mathrm{mg}(2 \mathrm{ml})$ of $0.5 \%$ heavy bupivacaine plus $0.5 \mathrm{ml}(25 \mathrm{gg})$ entanyl and $0.5 \mathrm{ml}$ saline (will addto make a total volume $3 \mathrm{ml}$ ). While patients in Group (B) received $(2 \mathrm{ml})$ of $0.5 \%$ heavy bupivacaine plus $0.5 \mathrm{~mL}(25 \mu \mathrm{g})$ fentanyl and $\mathrm{Mg}$ sulfate $0.75 \mathrm{mg}$ in $0.5 \mathrm{ml}$ (total volume $3 \mathrm{ml}$ ) was injected intrathecally. Demographic data,clinical data, onset and duration of sensory and motor block and also complications (hypotension, nausea and vomiting) related to regional anesthesia were recorded. Numrical Rating Scale (NRS) was recorded every 6 hours for the next 24 hours. Rescue analgesia (ketorolac $30 \mathrm{mg}$ ) was given when NRS was $>4$. Time of administration and total dose of rescue analgesia was calculated. The main results of our study showed that, there were significant increases in onset time and duration of sensory and motor block in $\mathrm{Mg}$ group. There were significant increase in time ofthe first dose of rescue analgesia in $\mathrm{Mg}$ groups than the control group. There were significant decrease in the number and dose of rescue analgesia in $\mathrm{Mg}$ groups than the control group.
\end{abstract}

Conclusion: The addition of intrathecal magnesium sulfate to intrathecal bupivacaine plus fentanyl in patients undergoing cesarean section fasten the onset of anesthesia and prolongs its duration. Also, it prolongs the duration and quality of analgesia with reduction of the use of additional analgesia and lesser side effects.

Key Words: Magnesium sulfate - Intrathecal - Bupivacaine - Analgesia - Normal cesarean section.

Correspondence to: Dr. Esam El-Din M. Abdalla, The Department of Anesthesiology, College of Medicine, Assiut University, Assiut, Egypt

\section{Introduction}

THE aim of post-operative analgesic management should be to provide adequate analgesia with minimal side effects. Spinal anesthesia provides fast and reliable segmental anesthesia with minimal risk for toxicity [1]

Regional anesthesia is a safe and inexpensive technique which is widely used in cesarean section. It reduces the risk of airway complications and avoids hemodynamic changes associated with laryngoscopy and intubation [2,3] . Recently, application of intrathecal adjuvants has gained popularity with the aim of prolonging the duration of block, better success rate and patient satisfaction $[2,5]$. Opioids such as fentanil are commonly used as additives to local anesthetics to prolong the duration and intensify the effects of subarachnoid block. However, significant side effects of opioids such as pruritus, urinary retention, respiratory depression, hemodynamic instability, occasionally severe nausea and vomiting may limit their use [4]

It has been shown that the duration of postoperative analgesia was prolonged when magnesium is given as an adjunct for peripheral nerve blocks [6]. A few clinical trials have examined the effect of adding intrathecal $\mathrm{MgSO} 4$ to anesthetic agents such as bupivacaine $[7,8]$. Antinociceptive effects of $\mathrm{Mg}$ are probably due to the regulation of calcium influx into the cell and antagonisation of N-methyl D-aspartate (NMDA) receptors. In the human body, calcium channel blockers can increase the analgesic effects of opioids. The analgesic effect of magnesium is due to its effect on NMDA receptors. N-methyl D-aspartate receptor has negative modulatory sites for agents such as magnesium. Furthermore, it is coupled with ion channels such as $\mathrm{K}+$ and $\mathrm{Ca}^{+}$. Magnesium causes 
a voltagedependent block on NMDA receptors [710]

\section{Patients and Methods}

After approval of Assiut University Hospitals Ethics Committee and written informed consent was taken from study participants, 60 women scheduled for elective cesarean section with spinal anesthesia was enrolled in this study. This study was conducted at Assiut University Women Health Hospital and started on October 2016 and ended on June 2017. Primary outcome was; onset of sensory and motor block, time to maximal sensory block, duration of sensory and motor block and Evaluation of post-operative pain. And secondary outcome was; duration of spinal anesthesia, evaluation of the need of supplemental analgesia in (time of 1 st dose, number of doses and total drug consumption), common side effects of studying drugs (nausea, vomiting, hypotension, pruritis, respiratory depression, urine retention and muscle weakness) and evaluation of the baby's health condition.

The selected patients was prepared preoperatively in the usual fashion, venous access obtained in the upper limb with a $18 \mathrm{G}$ catheter and patients received $500 \mathrm{ml}$ intravenous isotonic $\mathrm{NaCl}$ solution over 20 minutes at room temperature and aspiration prophylaxis was done (ranitidine $150 \mathrm{mg}$ and metoclopramide $10 \mathrm{mg}$ was given 2 hours before operation). Intraoperative monitoring by 5 leads ECG, pulse oximetry and noninvasive blood pressure.

The anesthesiologist performed a spinal anesthesia with the patient in the sitting position using sterile technique at the L3-4 interspace.

Subjects will be included in the study only if they meet all of the following criteria: Age 18 to 45 years, undergo elective cesarean section under spinal anesthesia, ASA physical status I-II, singleton pregnancy and at least 36 weeks gestation.

Subjects excluded from the study for any of the following reasons: Patient refusal, women with a history of cardiac, hepatic or renal diseases, women with allergy to amide local anesthetics or medication included in the study, women with any neurological problem and any contraindication of regional anesthesia.

Patients were randomly assigned to one of two groups (30 patients each), [Group (A) (control group), Group (B) (intrathecal magnesium sulfate group). Randomization was done by closed envlop method.
Patients in Group (A) will receive intrathecal $10 \mathrm{mg}(2 \mathrm{ml})$ of $0.5 \%$ heavy bupivacaine plus $0.5 \mathrm{~mL}$ $(25 \mu \mathrm{g})$ fentanyl and $0.5 \mathrm{~mL}$ saline saline (was added to make a total volume $3 \mathrm{~mL}$ ). While patients in Group (B) received $(2 \mathrm{ml})$ of $0.5 \%$ heavy bupivacaine plus $0.5 \mathrm{~mL}(25 \mu \mathrm{g})$ fentanyl and $\mathrm{Mg}$ sulfate $0.75 \mathrm{mg}(0.5 \mathrm{~mL})$ was injected intrathecally (total volume $3 \mathrm{ml})$.

After obtaining baseline values of hemodynamic variables, spinal anesthesia was performed in the sitting position using Quincke spinal needle 25G inserted via a midline approach through the L3-4 or L4-5 interspace under proper aseptic conditions. The patient was placed supine with a left lateral tilt to alleviate aortocaval compression. Oxygen was delivered to the mother by face mask at $3 \mathrm{~L} /$ minute. Bilateral sensory block to pinprick was tested in a cephalad to caudal direction on the midclavicular line bilaterally and once T6 block was established surgery was allowed to proceed.

IV fluids will administered as the anesthesiologist discretion per usual practice. If hypotension (fall of $>20 \%$ of MAP from baseline) occurred, vasopressors, $6 \mathrm{mg}$ ephedrine (per dose) was used. The blood pressure was rechecked 1 minute after each dose of ephedrine. If hypotension persisted after $30 \mathrm{mg}$ of ephedrine, an additional $2 \mathrm{ml} / \mathrm{kg}$ of isotonic $\mathrm{NaCl}$ solution was infused rapidly. Reactive hypertension is characterized as a blood pressure, $20 \%$ greater than baseline mean levels after the use of the vasopressor. Bradycardia is defined as a fall of $>30 \%$ of HR from baseline or $<50$ beats/ minutes. Bradycardia, and when associated with hypotension it was treated with $0.5 \mathrm{mg}$ of atropine IV.

All patients received oxytocin 5IU bolus IV slowly followed by infusion of $20 \mathrm{IU}$ on $500 \mathrm{ml}$ saline at rate $200 \mathrm{ml} / \mathrm{h}$, we allowed patients to eat after auscultation of intestinal sounds. The surgical technique was uniform in all groups. Upon completion of the cesarean section, the subject transported to the PACU.

\section{A- Pre-operative data monitoring:}

Demographic data, (ASA) physical status, assessment of vital signs and laboratory data included Complete Blood Count (CBC), liver function, urea and creatinine level and coagulation profile.

\section{$B$ - Intraoperative data monitoring:}

Vital signs were assessed every 5 minutes for the first 15 minutes and every 10 minutes thereafter until the end of surgery and every 30 minutes until spinal recovery, assissment of motor block after 
giving spinal anesthesia by (Modified Bromage Scale), assessment of sensory cold sensation to pin prick and a ssessment of APGAR score.

\section{Modified Bromage Scale:}

$0=$ No motor block.

$1=$ Inability to raise extended leg.

$2=$ Inability to flex knees.

$3=$ Inability to flex ankle joints.

\section{C- Post-operative data monitoring:}

The data will recorded every 6 hours for the post-operative 24 hours.

1- Post-operative hemodynamic (blood pressure, $\mathrm{HR}$, respirator rate and $\mathrm{sPo} 2$ ), numerical rating scales for post-operative pain (a numerical scale with the range of 0 to 10 is another type of pain scale that is used. The words "no pain" appears by the "0" and "worst pain possible" is found by the "10"). Supplemental analgesia in the form of (IM) $30 \mathrm{mg}$ ketorolac was given if the scale is $\geq 4$. This dose was repeated, according to the patient need (the dose, and total amount of given drugs was recorded) and side effects of the studied drugs are: Nausea, vomiting, hypotension, pruritis, respiratory depression, urine retention and muscle weakness or renal impairment.

\section{Statistical analysis:}

The data were tested for normality using the Anderson-Darling test and for homogeneity variances prior to further statistical analysis. Categorical variables were described by number and percent $(\mathrm{N}, \%)$, where continuous variables described by mean and standard deviation (mean, SD). Chisquare test and fisher exact test used to compare between categorical variables where comparison between continuous variables by paired and unpaired $t$-test. A two-tailed $p<0.05$ was considered statistically significant. All analyses were performed with the IBM SPSS 20.

\section{Sample size:}

Sample size of 29 cases for each group (completed to 30 cases) was calculated to be sufficient for $80 \%$ power to detect a difference of $20 \%$ in post-operative pain score (primary outcome variable) and time to first analgesic request (secondary outcome variable) to have a 5\% significance level (GraphPad Software) [11].

\section{Results}

There was no sgnicant results detected among two groups as regard demographic data (Table 1).
The results of our study showed that when magnesium added intrathecally to intrathecal bupivacaine and fentanyl it prolong the duration of motor block but this is not statsically fignficant. Also the Bromage score grade 3 was acheve in shoter duration in Group B than A but of no stastical significance $(p>0.01)$ (Table 2).

The sensory block to T6 was achived in shorter duration in Group B than group A, also the duration of sensory block was longer in Group B than Group A but these values were of no significant diffrences $(p>0.01)$. But the time of two Ssegment regression was prolnged in Group B than Group A $(p>0.01)$ (Table 3).

The numerical rating scale was significantly higher in Group A than group B at all times of study $(p<0.01)$ (Table 4$)$.

The time of first analgesic requirement showed sginficantly increasd in Group B than Group A ( $p$ $<0.01$ ). Also both the number of analgesic requests and the total consumption of ketolorac significantly increasd in Group A than Group B ( $p<0.01)$, (Table $5)$.

The results of this study also showed that there were insignificant differences between the two groups as regarding intraoperative and postpostopreative haemodynamics (mean arterial blood pressure and heart rate) also no stastical significant found as regard intraoperative and post-operative arterial oxygen aturation and respiratory rate $\left(\mathrm{SPO}_{2}\right.$ and RR). Also our study showed that, there were insignificant differences between the tow groups as regarding side effects (nausea \& vomiting and pruritis).

Apgar score of babies (at one, five and ten minutes) was similar in both groups.

Table (1): Demographic data and patients characterstics.

\begin{tabular}{|c|c|c|c|}
\hline & $\begin{array}{c}\text { Group A } \\
(\mathrm{N}=30)\end{array}$ & $\begin{array}{c}\text { Group B } \\
(\mathrm{N}=30)\end{array}$ & $\begin{array}{c}p- \\
\text { value }\end{array}$ \\
\hline Age (years) & $25 \pm 5.43$ & $27.85 \pm 8.32$ & 0.168 \\
\hline Weight (kg) & $69.2 \pm 12.64$ & $69.45 \pm 10.69$ & 0.945 \\
\hline Operative time & $44 \pm 9.81$ & $46 \pm 8.68$ & 0.480 \\
\hline Height (cm) & $166.3 \pm 7.2$ & $166.7 \pm 6.9$ & 0.633 \\
\hline \multicolumn{4}{|l|}{ Parity: } \\
\hline Primipara & $9(30 \%)$ & $7 \quad(23.3 \%)$ & 0.622 \\
\hline Multipara & $9(30 \%)$ & $9 \quad(30 \%)$ & \\
\hline Grandmultipara & $12(40 \%)$ & $14(46.7 \%)$ & \\
\hline
\end{tabular}


Table (2): Monitoring of motor block.

\begin{tabular}{llll}
\hline & $\begin{array}{c}\text { Group A } \\
(\mathrm{N}=30) \\
(\text { mean } \pm \mathrm{SD})\end{array}$ & $\begin{array}{c}\text { Group B } \\
(\mathrm{N}=30) \\
(\text { mean } \pm \mathrm{SD})\end{array}$ & $\begin{array}{c}p \text { - } \\
\text { value }\end{array}$ \\
\hline $\begin{array}{l}\text { Bromage score } \\
\text { grade 3 (minutes). }\end{array}$ & $4.6 \pm 1.85$ & $4.1 \pm 1.33$ & 0.319 \\
$\begin{array}{l}\text { Duration of motor } \\
\text { block (minutes) }\end{array}$ & $155.25 \pm 7.76$ & $159.45 \pm 12.1$ & 0.202 \\
\hline
\end{tabular}

N.S: Non-Significant $(p>0.05)$

$*$ : Significant difference $(p<0.05)$.

Table (3): Monitoring of sensory block.

\begin{tabular}{llll}
\hline & $\begin{array}{c}\text { Group A } \\
(\mathrm{N}=30)\end{array}$ & $\begin{array}{c}\text { Group B } \\
(\mathrm{N}=30)\end{array}$ & $\begin{array}{c}p \text { - } \\
\text { value }\end{array}$ \\
\hline $\begin{array}{l}\text { - Sensory block T6 } \\
\text { (minutes). }\end{array}$ & $3.75 \pm 1.33$ & $3.5 \pm 1.36$ & 0.645 \\
- Two segments \\
$\begin{array}{l}\text { regression (minutes). } \\
\text { - Duration of sensory } \\
\text { block (minutes). }\end{array}$ & $35.9 \pm 5.54$ & $42.7 \pm 6.59$ & $0.001 *$ \\
\hline $\begin{array}{l}\text { N.S: Non-Significant }(p>0.05) . \\
\text { *: Significant difference }(p<0.05) .\end{array}$ & & \\
\end{tabular}

Table (4): Numerical Rating Scal (NRS).

\begin{tabular}{lccc}
\hline & $\begin{array}{c}\text { Group A } \\
(\mathrm{N}=30) \\
(\text { mean } \pm \mathrm{SD})\end{array}$ & $\begin{array}{c}\text { Group B } \\
(\mathrm{N}=30) \\
(\text { mean } \pm \mathrm{SD})\end{array}$ & $\begin{array}{c}p \text { - } \\
\text { value }\end{array}$ \\
\hline $6 \mathrm{~h}$ & $5.35 \pm 3.33$ & $3.15 \pm 3.82$ & $0.049^{*}$ \\
$12 \mathrm{~h}$ & $8.55 \pm 1.05$ & $5.7 \pm 3.66$ & $0.003^{*}$ \\
$18 \mathrm{~h}$ & $5.95 \pm 1.96$ & $4.15 \pm 2.89$ & $0.030^{*}$ \\
$24 \mathrm{~h}$ & $5.05 \pm 1.32$ & $4.5 \pm 2.78$ & 0.401 \\
\hline
\end{tabular}

N.S: Non-Significant $(p>0.05)$.

$*$ : Significant difference $(p<0.05)$.

Table (5): Monitoring of post-operative analgesic requirments (IM ketorolac 30mg).

\begin{tabular}{lccc}
\hline & $\begin{array}{c}\text { Group A } \\
(\mathrm{N}=30) \\
(\text { mean } \pm \mathrm{SD})\end{array}$ & $\begin{array}{c}\text { Group B } \\
(\mathrm{N}=30) \\
(\text { mean } \pm \mathrm{SD})\end{array}$ & $\begin{array}{c}p \text { - } \\
\text { value }\end{array}$ \\
\hline $\begin{array}{l}\text { - Time of frist } \\
\text { requirment. }\end{array}$ & $5.33 \pm 3.03$ & $11.35 \pm 7.44$ & $0.001^{*}$ \\
- Number of requirments \\
$\begin{array}{l}\text { of ketorolac. } \\
\text { - Total requirments of } \\
\text { ketorolac. }\end{array}$ & $2 \pm 0.65$ & $1.4 \pm 0.99$ & $0.018^{*}$ \\
\hline $\begin{array}{l}\text { N.S: Non-Significant }(p>0.05) . \\
* \text { *: Significant difference }(p<0.05) .\end{array}$ & $40.5 \pm 28$ & $0.043^{*}$ \\
\end{tabular}

\section{Discussion}

The results of our study showed that when magnesium added to intrathecal bupivacaine and fentanyl it prolongs the onset of sensory block. And longer duration of motor and sensory block longest in intarthecal magnesium groupthan control group. Our findings are similar to that of Ozalevli et al., [9], who clarified that in patients undergoing lower extremity surgery, the addition of intrathecal $\mathrm{Mg}(50 \mathrm{mg}$ ) to spinal anaesthesia induced by bupivacaine and fentanyl significantly delayed the onset of both sensory and motor blockade. The delayed onset could be due to the solution of $\mathrm{MgSO} 4$ having a different $\mathrm{pH}$, which might explain our findings. Also, increase in metabolism of bupivacaine due to the activation of cytochrome P450 (CYP) by $\mathrm{Mg}$ may be responsible for the delayed onset [10]

Our resuts showed that,when magnesium added to intrathecal bupivacaine and fentanyl it provides longer duration of analgesia than bupivacaine and fentnyl. More potent analgesia reflected by NRS pain score as well as total analgesic requirements and number of analgesic requests were reduced in magnesium group than in control group.

The same findings were demonstrated by $\mathrm{Bu}-$ vanendran et al., [11], who demonstrated that addition of intrathecal magnesium a noncompetitive NMDA antagonist, to fentanyl prolongs spinal analgesia. The median duration of analgesia when $50 \mathrm{mg}$ of IT MAG was added to 25 ofentanyl was prolonged to 75 minutes compared with 60 minutes when 25 fentanyl was used with saline. This longer duration of analgesia was not accompanied by increased adverse events in patients undergoing surgery below the umbilical level and in laboring parturients.

Samir et al., [12] . Demonstrated that both i.v infusion of $\mathrm{Mg}$ sulfate and intrathecal $\mathrm{Mg}$ during THA surgery under spinal resulted in reduced posto-perative pain and analgesic consumption. Intraoperative infusion of $\mathrm{Mg}$ sulfate was associated with significant reduction in intraoperative MAP and blood loss aswell. And explained that as Magnesium $(\mathrm{Mg})$ is an inorganic ion that has a noncompetitiveN-methyl-D-aspartate (NMDA) receptor antagonis tproperty with antinociceptive effects in animals and human models.

In agreement with our results Shah, [13] who studied Magnesium sulfate infusion for postoperative analgesia after surgery under spinal anesthesia. Resulted in improved post-operative analgesia by delaying as well as decreasing the need of postoperative analgesics. It also prolonged the duration of sensory and motor blockade of spinal anesthesia. There was no significant difference in hemodynamic variables and sedation in both groups. And explained the analgesic properties of magnesium are due to the NMDAglutamate receptor blocking action, which hampers calcium entry into the cell and the initiation of central sensitization process. 
Matched with our study Arcioni et al., [14] in the study about combined intrathecal and epidural magnesium sulfate supplementation of spinal anesthesia to reduce post-operative analgesic requirements undergoing major orthopedic surgery patients were randomly assigned to one of four groups to receive as an adjunct to spinal anesthesia intrathecal $\mathrm{MgSO} 4$, epidural $\mathrm{MgSO}_{4}$ or intrathecal and epidural $\mathrm{MgSO} 4$ combined, or spinal anesthesia alone (controls). Reduced post-operative analgesic requirements relative to patients receiving spinal anesthesia alone in major orthopedic surgery. And explained that due to the anti-nociceptive actionof $\mathrm{Mg} 2$. The $\mathrm{Mg} 2$ ion blocks NMDA receptora ssociated channels in a voltage-dependent manner. NMDA receptor channels are ligand-gated ion channels that generate slow excitatory post-synaptic currents at glutamatergic synapses.

Also, Khalili and colleagues, [8] demonstrated that in patients undergoing lower extremity surgery with spinal anesthesia, the addition of $100 \mathrm{mg}$ IT $\mathrm{MgSO} 4$ to $15 \mathrm{mg}$ bupivacaine without opioid supplement, prolonged the duration of the sensory block ( 106.5 vs. $85.5 \mathrm{~min}$ ) compared to contro group, decreased postoperative analgesic consumption, and significantly prolonged the onset of spinal anesthesia.

Mitra et al., [15] clarified that in patients undergoing the caesarean section under hyperbaric bupivacaine spinal anesthesia, the addition of 50, 75, or $100 \mathrm{mg}$ magnesium sulfate provides safe and effective anesthesia, but $75 \mathrm{mg}$ of this drug was enough to lead a significant delay in the onset of both sensory and motor blockade, and prolonged the duration of sensory and motor blockade, without increasing major side effects.

Matched with our study, Banihashem et al., [16] who studied intrathecal $\mathrm{mg}$ in two groups in cesarean section (Group 1 intrathecal admnstration of $10 \mathrm{mg}$ of hyperbaric bupivacaine and $0.5 \mathrm{~mL}$ of normal saline. Group 2: Intrathecal administration of $10 \mathrm{mg}$ of hyperbaric bupivacaine and $50 \mathrm{mg}$ of magnesium sulfate) showed that hemodynamic parameters such as heart rate and systolic blood pressure were similar in both groups. Three patients in the magnesium sulfate group and one patient in the control group experienced nausea and vomiting. No neurologic deficit was observed in any of the patients. Apgar score of babies (at one, five and ten minutes) was similar in both groups.

While our results are in contrast to the study by $\mathrm{KO}$ et al., [17], who used two groups in patients did abdominal hysterectomy under general anesthesia in magnesium group, $50 \mathrm{mg} / \mathrm{kg} \mathrm{MgSO} 4$ a bolus dose was followed by a continuous intravenous infusion of $15 \mathrm{mg} / \mathrm{kg} / \mathrm{h}$ with a syringe pump for $6 \mathrm{~h}$. And control group using the same volum of normal saline. It demonstrate that the perioperative intravenous administration of $\mathrm{MgSO} 4$ did not increase CSF magnesium concentration and had no effect on post-operative pain, and that an inverse relation exists between CSF magnesium concentration and cumulative post-operative analgesic consumption. This is the first clinical report to show the relation between CSF magnesium concentration and postoperative analgesic requirement.

In contrast to our study, Banihashem and his colleagues [16], who reported that that the addition of intrathecal magnesium sulfate to bupivacaine is not desirable in patients undergoing cesarean section due to the delay in the onset of sensory blockade and the lack of significant effects of magnesium on post-operative pain.

In coclusion, we found that magnesium sulphate (a nonopioid drug) can be used as an adjuvant with bupivacaine intrathecally to increase the duration of post-operative analgesia,with no additional side effects. Mg can prolong the duration and improve the quality of analgesia than bupivacaine when used alone.

\section{References}

1- COOK T.M.: Combined spinal-epidural techniques. Anaesthesia, V. 55, No. 1, p. 42-64, 2000.

2- ROELANTS F.: The use of neuraxial adjuvant drugs (neostigmine, clonidine) in obstetrics. Curr. Opin. Anaesthesiol., 19 (3): 233-7, 2006

3- RASOOLI S., PARISH M., MAHMOODPOOR A., MOSLEMI F. and SANAIE S.: Effect of spinal low dose bupivacaine-sufentanyl for cesarean section in preeclamptic parturients on neonatal outcome. Shiraz. E. Med. J., 10 (4): 201-8, 2009.

4- SAXENA A.K. and ARAVA S.K.: Current concepts in neuraxial administration of opioids and non-opioids: An overview and future perspectives. Indian J. Anaesth., 48 (1): 13-24, 2004.

5- FAIZ S.H., RAHIMZADEH P., IMANI F. and BAKHTIARI A.: Intrathecal injection of magnesium sulfate: Shivering prevention during cesarean section: A randomized, double-blinded, controlled study. Korean J. Anesthesiol., 65 (4): 293-8, 2013.

6- LEE A.R., YI H.W., CHUNG I.S., KO J.S., AHN H.J., GWAK M.S., et al.: Magnesium added to bupivacaine prolongs the duration of analgesia after interscalene nerve block. Can. J. Anaesth., 59 (1): 21-7, 2012. 
7- PASCUAL-RAMIREZ J., GIL-TRUJILLO S. and ALCANTARILLA C.: Intrathecal magnesium as analgesic adjuvant for spinal anesthesia: A meta-analysis of randomized trials. Minerva Anestesiol., 79 (6): 667$78,2013$.

8- KHALILI G., JANGHORBANI M., SAJEDI P. and AHMADI G.: Effects of adjunct intrathecal magnesium sulfate to bupivacaine for spinal anesthesia: A randomized, double-blind trial in patients undergoing lower extremity surgery. J. Anesth., 25 (6): 892-7, 2011.

9- M.Ö ZALEVLI, T.O. CETIN, H. UNLUGENC, T. GULER and G. ISIK: The effect of adding intrathecal magnesium sulphate to bupivacaine-fentanyl spinal anaesthesia. Acta Anaesthesiol. Scand., 49: 1514-9, 2005.

10- JONG WHA LEE, MI KYEONG KIM, YANG-SIK SHIN and BON-NYEO KOO: The Analgesic Effect of Single Dose of Intrathecal Magnesium Sulfate. Korean J. Anesthesiol., Jun., 52 (6): S72-S76, 2007.

11- ASOKUMAR BUVANENDRAN, ROBERT J. MCCARTHY, JEFFREY S. KROIN, WARREN LEONG, PATRICIA PERRY and KENNETH J. TUMAN: Intrathecal Magnesium Prolongs Fentanyl Analgesia: Anesth. Analg., 95: 661-6, 2002.

12- ENAS M. SAMIR, SAHAR S. BADAWY and AMIRA REFAIE HASSAN: Intrathecal vs intravenous magnesium as an adjuvant to bupivacaine spinal anesthesia for total hip arthroplasty, Egyptian Journal of Anaesthesia, 29: 395-400, 2013.

13- PRERANA N. SHAH and YAMINI DHENGLE: Magnesium sulfate for post-operative analgesia after surgery under spinal anesthesia. Acta Anaesthesiologica Taiwanica 54: 62-4, 2016

14- R. ARCIONI, S. PALMISANI, S. TIGANO, C. SANTORSOLA, V. SAULI, S. ROMANÓ 1, M. MERCIERI, R. MASCIANGELO, R.A. De BLASI and G. PINT: Combined intrathecal and epidural magnesium sulfate supplementation of spinal anesthesia to reduce post-operative analgesic requirements. Acta Anaesthesiol. Scand., 51: 482-9, 2007.

15- MITRA JABALAMELI and SEYED HAMID PAKZADMOGHADAM: Adding different doses of intrathecal magnesium sulfate for spinal anesthesia in the cesarean section: A prospective double blind randomized trial. Adv. Biomed. Res., 1: 7, 2012.

16- BANIHASHEM N., BAHMAN HASANNASAB, ALI ESMAEILI and BORHANEH HASANNASAB: Addition of Intrathecal Magnesium Sulfate to Bupivacaine for Spinal Anesthesia in Cesarean Section. Anesth. Pain Med. Jun., 5 (3): e22798, 2015.

17- KO S.H., LIM H.R., KIM D.C., HAN Y.J., CHOE H. and SONG H.S.: Magnesium sulfate does not reduce postoperative analgesic requirements. Anesthesiology, Sep., 95 (3): 640-6, 2001.

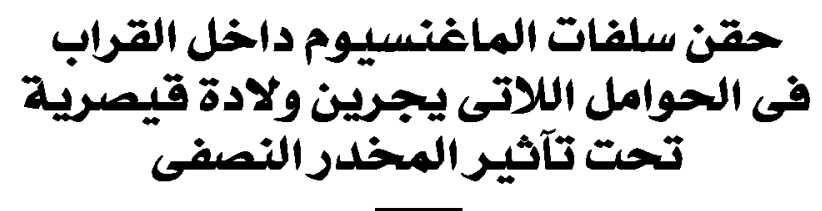

كبريتات الماغنسيوم هو آحد العناصر التى تستخدم كمساعد المخدر الموضعى مما يحسن تسكين الآلام بعد العملية الجراحية بعد تناوله

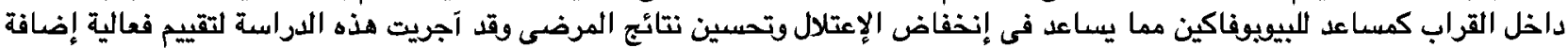

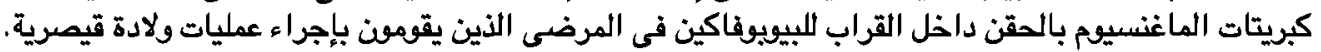
طريقة الدراسة: تم تقسيم المرضى إلى مجموعتين:

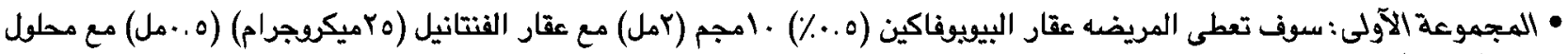

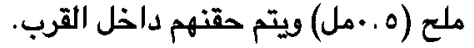

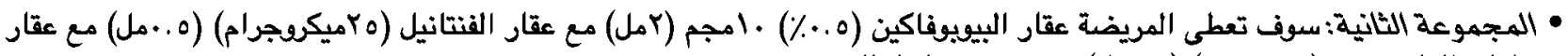

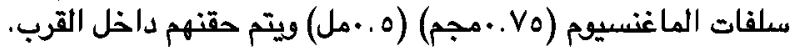

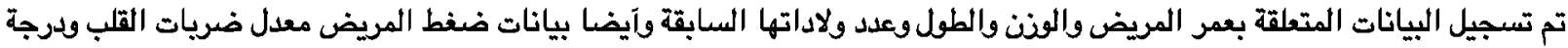

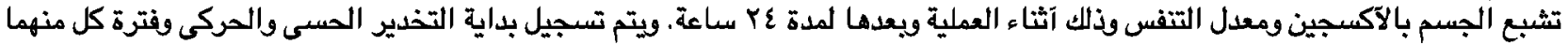

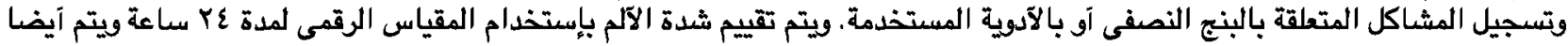

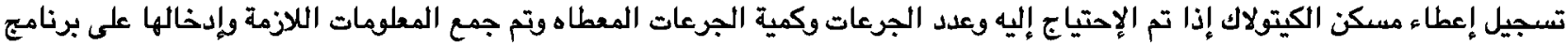
الإحصاء الإستخراج البيانات والإحصاء اللازمة اللدراسة.

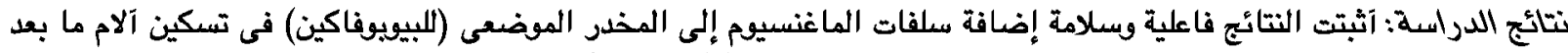

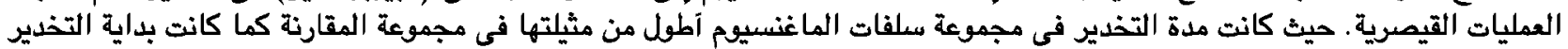

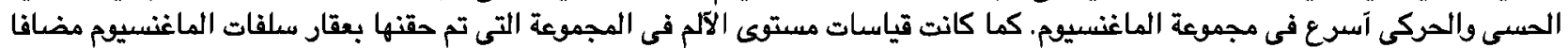

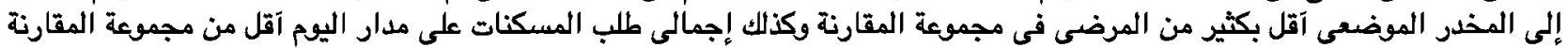

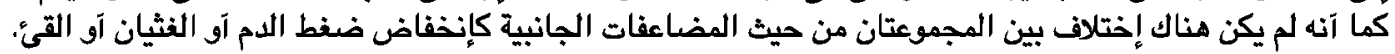

